\title{
The Cold War Origins of Global IR. The Rockefeller Foundation and Realism in Latin America
}

\author{
Álvaro Morcillo Laiz \\ SCRIPTS, Free University, Berlin
}

\begin{abstract}
The literature on global international relations (IR) has argued that the discipline develops in the footsteps of world politics, but no sustained attention has been given to more immediate causes such as the funders that pay for IR teaching and scholarship. These donor-recipient relations have only attracted the attention of authors interested in cultural hegemony and those contributing to the recent historiography of IR. Among the latter, some have studied how during the Cold War the Rockefeller Foundation attempted to buttress classical realism in the United States and Western Europe. This article connects and moves forward IR historiography and the global IR literature by shedding light on philanthropic foundations' attempts to further a specific IR theory-classical realismand area studies in the global south. The article argues that world politics influenced global IR, but this influence was mediated by highly contingent events. Even a proximate cause like science patronage, let alone "world politics," is not a sufficient cause capable of determining IR theories and disciplinary boundaries. Donors may achieve some impact but only under specific circumstances such as the ones explored here, that is, the donor is a unitary actor determined to advance its agenda by resorting to conditionality, alternative donors and funding are scarce, the discipline is either poorly or not institutionalized, and the recipient perceives the donor's preferences as legitimate. The article uses previously untapped, fine-grained, primary sources to unravel philanthropy's impact on Latin America's first IR center. Because science patronage is exposed to many sources of indeterminacy and to contingency, donors cannot determine scholarship, which makes cultural hegemony all but impossible. Still, IR scholars need to study their patrons to understand their discipline, in and outside Europe and the United States.
\end{abstract}

La bibliografía sobre Relaciones Internacionales (RI) globales sostiene que la disciplina se desarrolla al compás de la política mundial, pero no se ha prestado una atención sostenida a las causas más inmediatas, como los fondos que financian la enseñanza y el estudio académico de las RI. Estas relaciones entre donantes y beneficiarios solo han atraído la atención de los autores interesados en la hegemonía cultural y de los que contribuyen a la historiografía reciente de las RI. Entre estos últimos, algunos han estudiado el intento de la Fundación Rockefeller de apoyar el realismo clásico en los Estados Unidos y la Europa Occidental durante la Guerra Fría. Este artículo conecta y promueve la historiografía y la bibliografía de las RI globales al arrojar luz sobre los intentos de las fundaciones filantrópicas 
que buscan promover una teoría específica de las RI (el realismo clásico) y los estudios de área en el sur global. El artículo sostiene que la política mundial influyó en las RI globales, pero esta influencia estuvo mediada por acontecimientos de carácter muy contingente. Ni siquiera una causa inmediata, como el mecenazgo científico, ni mucho menos la "política mundial" son causas suficientes que puedan determinar las teorías de las RI y los límites disciplinarios. Los donantes pueden lograr cierto impacto, pero solo en circunstancias específicas como las que se exploran aquí; es decir, el donante es un actor unitario decidido a promover su agenda recurriendo a la condicionalidad, los donantes y la financiación alternativos son escasos, la disciplina está poco o nada institucionalizada y el receptor percibe las preferencias del donante como legítimas. El artículo utiliza fuentes primarias, hasta ahora inexploradas, para desentrañar el impacto de la filantropía en el primer centro de investigación en relaciones internacionales de la región. Dado que el mecenazgo científico está expuesto a muchas fuentes de indeterminación y a la contingencia, los donantes no pueden determinar los estudios académicos, lo que hace que la hegemonía cultural sea casi imposible. Aun así, los académicos de las RI necesitan estudiar a sus mecenas para entender su disciplina, dentro y fuera de Europa y los Estados Unidos.

La littérature sur les Relations internationales (RI) mondiales a soutenu que la discipline se développait sur les traces des politiques mondiales, mais aucune attention soutenue n'a été accordée aux causes plus immédiates telles que les financeurs qui subventionnent l'enseignement et les recherches en RI. Ces relations entre donateurs et bénéficiaires ont uniquement attiré l'attention des auteurs s'intéressant à l'hégémonie culturelle et des auteurs contribuant à l'historiographie récente des RI. Parmi ces derniers, certains ont étudié la tentative de la Fondation Rockefeller de soutenir le réalisme classique aux États-Unis et en Europe occidentale durant la guerre froide. Cet article associe l'historiographie des RI et la littérature sur les RI mondiales et les fait progresser en mettant en lumière les tentatives de fondations philanthropes de promouvoir une théorie spécifique des RI - le réalisme classique - et les études territoriales dans les pays du sud. Il soutient que les politiques mondiales ont influencé les RI mondiales, mais que cette influence a été régie par des événements très contingents. Même une cause immédiate, comme le mécénat des sciences politiques, et encore moins les " politiques mondiales ", n'est pas une cause suffisante capable d'impacter les frontières disciplinaires et théories des RI. Les donateurs peuvent avoir un certain impact, mais uniquement dans des circonstances spécifiques comme celles qui sont explorées ici, c-à-d, si le donateur est un acteur unitaire déterminé à faire avancer son programme en ayant recours à la conditionnalité, si le financement et les donateurs alternatifs sont rares, si la discipline est mal institutionnalisée ou n'est pas du tout institutionnalisée, et si le bénéficiaire perçoit les préférences du donateur comme étant légitimes. Cet articles s'appuie sur des sources primaires détaillées jusqu'ici inexploitées pour déterminer l'impact de la philanthropie sur le premier centre de RI d'Amérique latine. Le mécénat des sciences politiques étant exposé à de nombreuses sources d'indétermination et à la contingence, les donateurs ne peuvent pas avoir de rôle déterminant sur les recherches, ce qui rend l'hégémonie culturelle pratiquement impossible. Pourtant, les chercheurs en RI doivent étudier leurs mécènes pour comprendre leur discipline, en Europe et aux États-Unis comme ailleurs.

Keywords: global international relations, transnational actors, history of international studies

Palabras clave: Relaciones internacionales globales, actores transnacionales, historia de los estudios internacionales 
Mots clés: Relations internationales mondiales, acteurs transnationaux, histoire des études internationales

The main point is, of course, our needs.

Daniel Cosío to the Rockefeller Foundation

In the mid-1950s, alarmed by the activities of postcolonial states in the international arena, the president of the Rockefeller Foundation (RF), Dean Rusk, sought "a sharp increase in the funds available for underdeveloped areas." ${ }^{1}$ Rusk was alarmed and so was the US Secretary of State and RF trustee John Foster Dulles, who had asked Rusk whether the RF could work toward a "Bandung conference in reverse." This increase in funds enabled the RF and the Carnegie Corporation to set up a series of programs to train diplomats and international relations (IR) faculty from US-friendly governments in the "new nations" (RF 1957, 5). These programs were designed to help postcolonial states conduct "their own foreign policies [...] responsibly" (RF 1961, 27). The programs were affiliated with both US and European universities or based in major regional capitals such as New Delhi and Mexico City. Between 1955 and 1965, the RF alone spent almost \$4 million training diplomatsadjusted for inflation, this amounts to more than $\$ 34$ million today. ${ }^{3}$ Diplomacy taught by scholars of IR was not the only beneficiary of the new foreign policy and RF's munificence; in 1954, funding to area studies in the United States and, to a lesser extent, abroad increased five-fold. ${ }^{4}$

At first sight, this episode of philanthropic liberality confirms two common claims in the IR literature. One is that global IR "actually [tracks] quite closely the nature and practices" of decolonization and of world politics generally (Acharya and Buzan 2019, 2). First spelled out by Amitav Acharya, global IR is a proposal for the disciplines that combine a political and an intellectual dimension (Acharya 2014). Simply put, the political dimension calls for more participation from IR scholars from the global south (Hurrell 2016). Thus, Acharya, the first ISA president born outside the West, should be a precursor to many. In its intellectual dimension, global IR aspires to incorporate non-Western, pre-Modern thinking on IR into the disciplinary canon (Shahi 2018; Fierke and Jabri 2019). Exploring this intellectual dimension, Acharya and Buzan have published work that revisits the disciplinary history of IR since 1919 against the foil of the West's international relations (Acharya and Buzan 2019). A connection between world politics and IR undoubtedly exists, as Acharya and Buzan claim, but one of the goals of this article is to show that they obviate certain complexities intrinsic to the history of IR and the social sciences generally.

In order to show how the discipline is exposed to the power relations and vagaries of world politics, Acharya and Buzan have also contributed to global IR by studying the discipline in different countries across continents, and other authors have joined the fray (Tickner and Wæver 2009; Acharya and Buzan 2010; Tickner and Blaney 2012). However, in this literature, global IR funders, usually philanthropic foundations such as the RF, are only mentioned en passant, if at all (Acharya and Buzan 2019, 163). This neglect is not commensurate with the likeliness of philanthropic foundations having transmitted waves of changes from academic centers to the global south's cash-strapped universities (neither it is commensurate to foundations' early and pronounced internationalism; Sluga and Clavin 2016, 13).

\footnotetext{
${ }^{1}$ March 12, 1956; in Rockefeller Archive Center (RAC), Rockefeller Foundation collection, RG 3.1, 910, Box 9, Folder 79. Unless otherwise indicated, all sources are from this collection; misspelled words have been amended. All translations are mine.

${ }^{2}$ Rusk, diary entry, October 10, 1956, RG 12.

${ }^{3}$ Author's estimation based on the RF's Annual Reports. Inflation adjustments are from the US Bureau of Statistics CPI Inflation Calculator.

"Over-all support for area studies," January 20, 1955; RG 3.2, Series 900, Box 31, Folder 165.
} 
Despite this generalized neglect, Arlene Tickner has presented evidence that in the 1980s, the Ford Foundation (FF) shaped Latin American IR agendas (Tickner 2002, 131-35; 2013, 633). Even within the United States, FF had successfully pushed the behavioralist revolution, permanently altering political science (Hauptman 2012). Overall, donors' intentions and impact have been left mostly unexamined in the global IR literature as though they were inconsequential.

The RF's liberality in supporting global IR would seem to confirm a second claim. According to cultural hegemony scholars, donors' funding reflects "international developments which transmit their ideological currents to the periphery" (Cox 1983, 170). For them, "Gramscian hegemony has at its core a power technology that has proved spectacularly successful in building hegemony and managing or preventing radical change" (Huo and Parmar 2020, 239). These claims are explicitly global, broad, politically relevant, and intuitively plausible (Berman 1983; Parmar 2012; Huo and Parmar 2020), but the sociology of science teaches us that the donor's impact is highly contingent and exposed to indeterminacy (Turner 1999, 199; Solovey 2013, 2020, chap. 9). This difficulty may explain why scholarship on global IR so often tiptoes around funding problems.

By contrast to global IR's neglect of donors, a streak of recent IR scholarship has shown how since the late 1950s, the RF endorsed the German émigrés' version of classical realism, namely Hans Morgenthau's. Supported by his former student, Kenneth W. Thompson, who worked for the RF's Division of the Social Sciences (DSS), realists advanced their idea of IR: they used IR theory to sever IR from political science and tried to trace a disciplinary boundary between the study of international relations and what they saw as an increasingly positivist discipline. These realists excluded behaviorists such as Charles Merriam, Harold Lasswell, and his former students' modernization theory (Koskenniemi, 2004, 468; Guilhot 2011b, 2017, chap. 1). They also disregarded liberal internationalists, such as Quincy Wright, and even second-generation realists, such as Morton Kaplan and Kenneth Waltz, and anyone propounding hard concepts of social science and rationality that foreboded neorealism (Guilhot 2017, chap. 1, 5). In fact, the opening salvo of the realist counterattack had been a conference, to establish an IR theory that could co-opt political theory into realist IR while leaving out behaviorism (Guilhot 2011b; Hauptmann 2020). After 1960, the RF took this interest in diplomats and IR up into its University Development Program, which Thompson eventually co-led (Hauptmann 2020, 626). With its focus on foundations as science patrons, this IR literature has added one donor to earlier studies on another crucial patron: the US army and government, which since the World War II had changed IR and comparative politics (Gilman 2003; Oren 2003).

Valuable as this research on the patrons of US IR is for understanding disciplinary history, none of these authors has raised the question of whether these patrons similarly promoted IR in the global south. Did Thompson use RF resources to support realists' IR theory outside the United States and Western Europe? If IR scholars in parts of the global south adopted realism, was this simply because the RF provided local scholars with resources? Or did donors bind awards to the fulfillment of conditions? Did recipients consider these conditions legitimate? Finally, did donors succeed in overcoming the "clumps of indeterminacy" inherent to science patronage (Turner 1999, 218), eventually shaping global IR? These questions are all the more important since global IR scholars "criticize realism's claim that its knowledge applies universally" (Foulon and Meibauer 2020, 1204).

In this article, I argue that since the late 1950s, the RF and other foundations institutionalized the discipline abroad, altering the history of IR in the global south. As the RF became an IR powerhouse of global reach, trying to propagate the norms of Western diplomacy among the diplomats and IR faculties of Asia, Africa, and Latin America, it simultaneously promoted a realist IR, but of a certain kind: Morgenthau's classical realism. At the Colegio de México, the case studied 
here, the RF institutionalized realist IR, (re)drew disciplinary boundaries, and moved IR into a stand-alone department. These three traits characterize the proposal for IR that Thompson and the other realists advanced from behind the DSS trench (Guilhot 2011b; 2017, chap. 1; Hauptmann 2020). Additionally, officers from the RF's Division of Humanities successfully maneuvered to incorporate area studies into Mexican IR. The RF's successes in Mexico may have also facilitated Latin American IR scholars' later interest in realism and its adaptations. Going beyond global IR, this article points at the argument's implications for the IR scholarship on legitimacy, cultural hegemony, and donors.

To account for the significant impact of RF science patronage, I identify some causes that operate within the donor and others that operate within the recipient. A cause operating within the RF was the longstanding and adept use of ex-post and structural conditionality (Babb and Carruthers 2008, 15, 16). Another cause is Thompson's realist grip on the DSS and the discrete involvement of the officers from the Humanities. Within the recipient, a fundamental part was played by the Colegio's Daniel Cosío Villegas, a scholar and academic entrepreneur. Put in Bourdieusian terms, Cosío succeeded in turning political capital and scientific capital from other disciplines into (in this case) IR capital. A final cause operating within the recipient is how Cosío and of other Colegio members reacted to the conditions the RF set and the "advice" its officers proffered: Cosío and his colleagues attributed them a significant degree of both internal and external legitimacy (Weber 2019, 111). Legitimacy as a concept has been frequently reduced to internal, normative reasons to obey (Hurd 1999, 381) or decomposed in a myriad of elements (Hurd 2019; Tallberg and Zürn 2019). In reality, as the article shows, the numerous elements that impinge upon belief in legitimacy can be classified as either external or internal reasons; the latter bolster the former. Other causes are ecological and time-related. In Mexico, only one foreign donor was in sight and domestic resources were insufficient. When only one donor (or lender) is available (Sikkink 1998, 237; Babb and Carruthers 2008, 18), and in an emerging field (Bourdieu 1992, 465510; Sending 2015, 28), the donor's clout multiplies and so did the effects of RF conditionality.

As the article explores the causes of donor impact, it also opens the black box of donors' decision-making. Generally speaking, IR scholars have written books on recipient organizations (Clark 2001; Forsythe 2005; Hopgood 2013) while they have seldom focused on specific donors (Wong, Levi, and Deutsch 2017; Fejerskov 2018). After identifying the origins of a donor's policy, including the officers' professional allegiances, a different view of donors is here offered to the reader. This article's close-up of the RF, its policy, and officers' professional allegiances constitutes an alternative to most of the existing IR literature, which considers donors as fungible actors without distinctive agendas whose action is brought to a minimum common denominator by the logframe and other management tools (Cooley and Ron 2002; Krause 2014). Moreover, this literature's one-side emphasis on resource dependence is compensated here by the article's concern with internal legitimacy.

Through its focus on donors, this article adopts an alternative perspective to a streak in IR scholarship that has paid attention to donors but only as a way to explain INGOs. For instance, research on how prestige attracts donors has shown the downside of such success: a plurality of donors curbs INGOs' autonomy (Stroup and Wong 2017). Other IR research explores how INGOs from the "democracy establishment" advance their agendas between the Scylla of donors and the Charybdis of transitional states (Bush 2015, chap. 6; Swedlund 2017). Research on transnational advocacy has considered donors as equal, paying members of a partnership to which activists contributed ideas (Keck and Sikkink 1998). In short, the IR literature takes donors as givens to which INGOs and other recipients adapt their strategies while this article considers donors as autonomous actors with their own agendas. 
This article offers the first analysis of science patronage funding to an IR center in the global south. The focus of the article is placed upon how the RF negotiated with the Colegio de México over its Centro de Estudios Internacionales (International Studies Center; CEI). Among the IR centers in the global south, the CEI was second only to New Delhi's ISIS (Indian School of International Studies). Inaugurated with explicit regional, inter-American ambitions, the CEI combined research with a degree program and published the first Latin American IR journal-Foro Internacional. Thus, the CEI soon became a point of reference within Mexico, displacing the Faculty of Political and Social Sciences at the Universidad Nacional Autónoma de México (UNAM; Romero 1981; Tenorio 2009, 106-13). In its Latin American context, the CEI preceded the second IR center in the region, inaugurated in Santiago de Chile, by six years (Véliz 1967); the CEI's IR degree was offered fourteen years before the University of Brasilia began to teach a second one (Ochoa 2011; Jatobá 2013, 38; Alejandro 2018, chap. 1).

The importance of the CEI for the history of Latin American IR is partly the result of the Colegio and Mexico itself occupying a prominent place in the history of higher education in the region. When the CEI opened its doors in 1960, the Colegio was still a small publicly financed research center that offered highly selective graduate programs in the humanities and the social sciences (Lida, Matesanz, and Zoraida 2000; Lida 2018; Morcillo Laiz 2019b). Among the Latin American centers comparable in size and focus, the Colegio was on track to become "unrivaled" (Levy 1996, 51). Actually, within ten years, the Colegio's income grew almost five-fold; twenty years later, in 1980, the Colegio moved to its current seat, where nowadays around one hundred and seventy scholars teach five hundred students. ${ }^{5}$ Moreover, in the Latin American Cold War context, Mexico was politically stable and its capital a hub of the publishing industry and a beacon for refugee scholars.

The article relies on a wealth of previously unused primary sources. Most of them stem from the RF records on the Colegio, but others from the Colegio's archive. Other Mexican sources used here include biographies, obituaries, and autobiographical writings.

The article proceeds as follows: The first section explains how in the 1950s, the RF's DSS turned toward IR, realism, and global ambitions. The second section introduces the reader to the RF-Colegio negotiations. Then, the third section examines what the Colegio did to fulfil the RF's conditions for support. Next, the fourth shows how Cosío's plans to bring the Colegio into the social sciences morphed into an IR center along the lines favored by RF policy and officers. In the conclusion, I spell out the reasons why RF support to IR in Mexico was consequential for Latin American as well as the implications for global IR and other strands of IR literature.

\section{The RF, Realism, and Global IR}

During the interwar period, the RF and its predecessor, the Laura Spelman Memorial Fund, became the social sciences' most important private funder (McCaughey 1984; Fisher 1993; Rietzler 2009, 2014). This is particularly true in the specific case of IR, even if the Carnegie Endowment for International Peace preceded the RF in granting some forms of patronage to IR. Among the RF's wide range of IR-related activities were co-financing the International Studies Conference, the earliest IR research centers, and granting fellowships to individual IR scholars (Rietzler 2008, 61; 2009; 2014; Guilhot 2011c, 2017; Kuru 2017). In the United States, recipients included New York's Council of Foreign Relations, Yale's Institute of International Studies, and its successor, Princeton's Center of International Studies (Parmar 2012, 76-79; Hauptmann 2020; McCourt 2020), and in Europe, the Royal Institute for

\footnotetext{
${ }^{5}$ FF collection, Reports, "El Colegio de Mex́ico: An Evaluation" (001514), 1969, p. 32; El Colegio de México, Informe de actividades, 2020, numeralia.
} 
International Affairs and, among other smaller operations, the University of Heidelberg and Berlin's Hochschule für Politik (Rietzler 2008, 74). While the RF was seriously committed to IR, the truth is that this support was only a fraction of what the RF allocated to economics. Its grantees in this discipline, which included Simon Kuznets's national income accounts, the Brookings Institution, and the National Bureau of Economic Research (Rutherford 2011), confirm RF's prominence as a patron of economics between 1929 and 1960. Toward the end of this period, RF leaders wanted to reboot its social science program.

The reasons for this radical change were the Cold War and decolonization. In the Bandung aftermath, Rusk "brooded about the anti-Western attitudes of former colonial nations now members of the UN" (Cohen 1980, 83), so he and the RF trustees decided "to embark on an expanded program of aid to the developing countries of the world" (RF 1957, 7). Rusk wanted all RF divisions to recalibrate their programs in light of these global ambitions; the DSS officers and budget had to pay an unseen degree of attention to countries outside the Western core-previously, all spending had been in Europe and North America. The overhaul most affected the DSS's geographical focus, which expanded beyond the United States and Europe. At the time, many other US actors involved in research and higher education also began to pay for IR and area studies research. The newest patrons were the US government and military and the major philanthropic foundations, but the RF was the only one that systematically funded IR centers abroad (McCaughey 1984; Oren 2003, chap. 4; Engerman 2010; Solovey 2013, 2020). At the RF, the DSS' global turn was accompanied by changes in the disciplinary equilibrium: the long-standing emphasis on economics was watered down while political and IR theories got a boost. As a result, economics lost significance in favor of the international realm.

In fact, the DSS experienced a revamping. The standing of economists at the RF declined as Thompson's career skyrocketed. In 1956, the DSS was initially directed by an economist, Norman S. Buchanan, and employed two other economists, a sociologist, and a political scientist: Thompson (RF 1958, xxii). At the end of the period, in 1963, Thompson had been the DSS director and was eventually promoted to RF vice-president, benefitting from contingent events. One was the sudden death of the previous DSS director, Buchanan, in April 1958, another Rusk's appointment as President John F. Kennedy's secretary of state in 1961. Rusk, in turn, named the former RF vice-president US ambassador. By the time Thompson inherited the position of vice-president, the DSS employed two other political scientists, two economists, and a sociologist (RF 1964, ix). Meanwhile, the DSS had been merged with the Humanities, further diluting the influence of economists. More importantly, the DSS's new director was Joseph E. Black, a political scientist and Thompson's former student. In a proof of Thompson's firm grip on all social science matters at RF, Black was promoted from field staff to director within only two years. By then, the strongest discipline at DSS was political science or, to be more precise, realist IR.

In his ascendance within the RF, Thompson was not alone. This has been overlooked. Guilhot, for instance, thinks that Thompson "almost singlehandedly oversaw the international program of the foundation" (Guilhot 2011a, 15). In reality, Thompson relied on other realists whom he had previously brought to the RF. One of them, Charles M. Hardin, a political scientist, was a former faculty member at the University of Chicago, where he had studied with Morgenthau (Frei 2018, 63; Russell 2018, 150). The third DSS political scientist, Gerald Freund, considered Morgenthau's Politics among Nations was comparable to Aristotle's Politeis. ${ }^{6}$ As well as being realists, Freund and Hardin were apt professionals: Hardin became a major scholar of US constitutionalism and Freund, who in his memoires admitted having admired Thompson, later set up the MacArthur Foundation's "genius grants"

${ }^{6}$ Freund to Thompson, November 14, 1960; RG 2, 1960.323. 
(Freund 1996, v, chap. 3). In brief, economists had lost control over the RF's DSS to a tight-knit group of able realists.

Thompson and his officers skewed the DSS program toward their vision of IR and of realism. As the broad intellectual tradition that it is, realism has diverse roots. Among them are the thinking of British imperial and US military elites and others that preceded Edward H. Carr (Hobson 2012, chap. 5; Ashworth 2014, chap. 5). However, the realism that benefitted from the DSS program at RF had different, Germanic roots and barely hidden Weberian undertones that evoked his political writings and late vocation lectures (Turner 2008; Morcillo Laiz 2019a). Today, labeled classical realists, Morgenthau and his former student, Thompson, understood IR as a power-centered discipline, which nonetheless entertained secondary interests in diplomacy and international law (Thompson 1965; Koskenniemi 2004, 460, 464). They did so with the help provided by a coterie of advisors, who in many cases were linked to recipients of RF munificence such as the Council on Foreign Relations and Princeton's Center of International Studies. Among the scholars Thompson would turn for advice were Morgenthau, Wolfers, William T.R. Fox, and Paul Nitze (Guilhot 2011c, 2017, 49-52; Rajaee 2016, chap. 1).

During the 1950s, realists "had an unusually easy and rapid academic success" (Donnelly 1995, 185). In addition, they also succeeded in accessing the corridors of power. A realist university professor like Morgenthau was invited to lecture at a war college and then flown to his next engagement by the US Air Force (Guilhot $2017,8)$. Years earlier, one of realism's advocates, George Kennan, delivered the justification for the US policy of containment (Gaddis 2006, 29). In brief, realists were, for a time, power's blind oracles (Kuklick 2007, chap. 4) and in the 1950s "thoroughly" dominated "the academic study of international relations (Donnelly 1995, 185).

Realism, as understood by Morgenthau and Thompson, overlapped in certain respects with Rusk's thinking about IR. He was a liberal internationalist who, therefore, valued realists' secondary interests in diplomacy and international law (Rusk 1959, 365; 1990, 229, 412-13; Zeiler 1999). In Guilhot's apt brief, both realists and liberal internationalists thought that diplomats should turn international organizations into an instrument for the West to manage its relations with the former colonies (Guilhot 2014, 715). This overlap may have facilitated Thompson's collaboration with Rusk. In the late 1950s, they were "most directly concerned with problems of international relations research." As shown below, Rusk participated directly in the negotiation of some IR grants.

Apparently, the collaboration between Rusk and Thompson moved the former to consecrate realism as the RF's worldview. In his 1957 President's Review, Rusk wrote: "The analytical concept of a struggle for power has brilliantly illuminated turbulent events for students of international politics" (RF 1958, 4). By then, the IR program's backbone included the terms "training of diplomats," "diplomatic practice," and "multilateral diplomacy". Other topics Rusk and Thompson emphasized were the United Nations and the domestic foreign policy process (RF 1961, 27, 213, 22021). When in 1961 Rusk left the RF, "international relations, diplomacy and related subjects" were part of the basic social sciences (RF 1961, 75).

The preceding account moves from IR theories to RF policy, but policy was also shaped by political considerations: diplomats mattered because of what Rusk wanted from the newly independent countries. He stated it openly in his last President's Review (RF 1961, 27):

Not the least of them [responsibilities of the new states] is the obligation to shape their own foreign policies, to execute them through traditional diplomatic channels and through their membership in the United Nations, and to do so effectively and responsibly.

${ }^{7}$ RG 3.1, Series 910, Box 8, Folder 67, Gerald Freund, "International Relations Program” (1961). 
In other words, through its program for diplomats, the RF wanted to preserve diplomatic practice as it was prior to decolonization.

To obtain this, RF trustees supported "efforts to build up a corps of diplomats thoroughly conversant with the practices and procedures of modern international relations" (RF 1961, 26-34, 220-22). Among the connected strategies employed was bringing together US scholars and senior diplomats from the "new nations," to spend several months at Harvard's Center for International Affairs. Another, less elitist, effort was granting fellowships to young foreign service officers for advanced study at Columbia's School of International Affairs or the Geneva Graduate Institute of International Studies. A third focused on offering part-time training on foreign policy formation to junior diplomats in Washington; if they were in New York, the focus would be on the UN and multilateralism. With the exception of the Harvard program, these efforts were implemented by the Carnegie Endowment for International Peace. This philanthropy also obtained RF funding to organize "institutes in diplomacy" in various developing regions to meet the need of "short-term intensive training" (RF 1963, 39). On top of these efforts, which cost more than \$34 million in current dollars, the RF supported several local efforts such as New Delhi's ISIS (its main funder was the FF; RF 1957, 197; 1958, 322). Thus, the RF also intervened in the training of future diplomats.

Against the backdrop of the RF's worries about decolonialization, it is understandable that Thompson thought that the Colegio's IR "program seems compatible with our interest in 'diplomats,' etc., although we have talked more about Asia and less about Latin America in this connection." ${ }^{8}$ US worries about decolonization were followed by worries about Cuba's communist drift, Nikita Khrushchev's endorsement of the wars of national liberation, and the missile crisis. To some extent, this explains why after 1960, US foundations and other donors expanded support to universities abroad (Levy 2005). The next section shows how the RF's-and Thompson's-early interest in diplomats played out with the Colegio de Mexico's CEI.

\section{The Colegio de México, the RF, and the Origins of the CEI}

After visiting Mexico City, an RF officer reported that the Colegio was housed in "a large, rather monstrous old villa." ${ }^{9}$ Built in prerevolutionary times, the Colegio's seat was a former family home. Its bedrooms had been turned into miniature research centers and its living room into a library. Housing in close quarters, however, was only one of the Colegio's many problems. Established in 1938 in Mexico City to host Spanish émigré scholars, most of them liberals, the Colegio had survived World War II, thanks to the RF's timely grants for the humanities (Lida, Matesanz, and Zoraida 2000, 299). ${ }^{10}$ In the early 1940s, the Colegio received RF support thanks to the Humanities officers, who were adamant that the Colegio was an "enterprise essentially liberal with regard to personnel and tendencies." ${ }^{11}$ During the Cold War, politics and RF decisions would continue shaping the history of the Colegio.

From the 1940s, the RF awarded almost uninterrupted support to the Colegio, but by the mid-1950s it was on life support. Operating on a shoestring of public funding, once the RF stopped financing the Colegio's teaching program in history, it had to close. Besides budgetary problems, the Colegio's troubles included diverging opinions within its dual leadership. At the helm were Alfonso Reyes, a perennial candidate for the Nobel Prize in literature, and Cosío, the aforementioned

\footnotetext{
${ }^{8}$ Thompson to Buchanan and Montague Yudelman, October 19, 1957; RG 1.2, 323S, Box 62, Folder 485, hereafter F485.

${ }^{9}$ Yudelman, trip diary, February 25, 1959, F485.

${ }^{10}$ Thompson to Buchanan and Yudelman, October 18, 1957; on Reyes's resistance, Yudelman, trip diary, May 15 , 195; F485.

${ }^{11}$ William Berrien to David H. Stevens, both RF officers for the Division of the Humanities, October 5, 1942; RG 1.1, 323R, Box 22, Folder 178, hereafter F178.
} 
academic entrepreneur, who had long been the Colegio's "real guiding hand."12 While Reyes thought of the Colegio as an Institute for Advanced Study of sorts, Cosío, the Colegio's secretary, wanted to reactivate its teaching programs and expand from the humanities to the social sciences.

Cosío's ambition seems a most reasonable one, given his trajectory. He graduated in law at the UNAM and then studied mainly agricultural economics in the United States and Great Britain-some stretches of Cosío's Wanderjahre were funded by a Laura Spelman Rockefeller Memorial fellowship. ${ }^{13}$ Upon his return to Mexico, he introduced economics to the UNAM (Babb 2001, 30). After a stint as a diplomat during the Spanish Civil War, he then headed the Mexican central bank's research department and was a delegate to the Bretton Woods Conference (Thornton 2021). Thanks to his outstanding organizational skills, in the 1940s Cosío built the Fondo de Cultura Económica, the only publishing house capable of distributing its books across the United States; this was a feat that the RF and the FF, possibly encouraged by the US Central Intelligence Agency (CIA), later tried to imitate. ${ }^{14}$ After 1948, a slew of RF grants to the Colegio enabled Cosío to pursue a new parallel career as a self-taught, liberal historian of Mexico (Krauze 2001, 239-43; Ortoll and Piccato 2011). Between 1957 and 1959, Cosío led the Mexican delegation to the UN Economic and Social Council (ECOSOC). Shortly thereafter, he published his first book on Mexico's foreign policy (1960).

In the late $1950 \mathrm{~s}$, the RF was not on life support, but circumstances were also exceptional. In January 1956, Charles B. Fahs, the RF director for the humanities, visited Reyes at his home, "as usual in his large library" and discussed the Colegio's finances and administration. ${ }^{15}$ The next day, Fahs met Cosío in the "monstrous, old villa." Neither the timing nor the fact that Fahs came with the DSS director, Buchanan, was accidental. The RF had approved its "expanded program of aid" for developing countries (RF 1957, 7), but the DSS had no beneficiaries in Mexico, an obvious potential recipient and neighbor. ${ }^{16}$ Thus, when Cosío expressed to Fahs "his interest in developing at the Colegio work on international relations," Fahs immediately referred Cosío to Buchanan. ${ }^{17}$ Back in New York, Fahs reminded Buchanan of the Colegio's program of foreign service training, and they agreed that hereafter the DSS officers should be cognizant of this. ${ }^{18}$ The Humanities officers nonetheless kept a watchful eye on this DSS program.

Despite Fahs and Buchanan's encouragement, the summer arrived without the RF receiving a specific request from the Colegio. At this point, Fahs sought help from Cosío. ${ }^{19}$ Fahs's letter made his eagerness to fund the Colegio transparent. This is remarkable because the RF policy banned officers from suggesting projects to potential recipients. Unsurprisingly, after Cosío forwarded the letter to Reyes, the latter responded that he would be "encantado" (delighted) to talk with Cosío about RF. Soon thereafter, possibly enticed by Fahs's eagerness, Reyes resumed contact with the RF. Despite Fahs's overture, in the following months, officers from the Humanities still felt compelled to ask whether "the Colegio was interested in the social sciences" and about "a school for training Mexicans for the foreign service." 20 However, these questions were not banned by the RF policy (unlike Fahs's letter to

\footnotetext{
12 www.nobelprize.org/nomination/redirector/?redir=archive/; Fahs, diary entry, October 2, 1951 ; RG 12.

${ }^{13}$ RG 10.2, 323E.

${ }^{14}$ FF collection, Reports, "Final Evaluation and Recommendation for Termination of Grant to the Interamerican Center for Scholarly Books (CILA), PA65-92A" (007719), 1972.

${ }^{15}$ Fahs, diary entry, January 16, 1956, RG 12.

16 “Over-all support for area studies," January 20, 1955; RG 3.2, Series 900, Box 31, Folder 165.

${ }^{17}$ Fahs, diary entry, January 17, 1956; Buchanan, diary entry, January 17, 1956; F485.

${ }^{18}$ Fahs to Buchanan, interoffice memorandum, March 29, 1956; Buchanan to Fahs, April 5, 1956 ; F485.

${ }^{19}$ Fahs to Cosío, July 26, 1956; RG 2, 1956.323, Box 54, Folder 355.

${ }^{20}$ Fahs, trip diary, December 11, 1956; RG 12; Harrison, diary trip, December 8, 1956, F485; Cosío's undated forward to Reyes with their handwritten annotations is in RF folder, Archivo Histórico de El Colegio de México (AHCM).
} 
Cosío): once a potential recipient had raised an idea, officers were allowed to ask how this "interest" had developed. ${ }^{21}$ Using the loophole created by Fahs's letter, the Humanities officers discreetly kept the Colegio negotiations with DSS alive.

The Humanities officers' motives were not made explicit in the record. One reason why they might have been discreet is that their behavior could be considered biased and intruding on DSS's remit. Obviously, one motive is that the Humanities officers admired Reyes. Regarding Cosío, they knew, like the DSS officers, that he could behave as "his usual charming self." ${ }^{22}$ However, apart from personal preferences, the Humanities officers also had more objective reasons why they wanted the DSS to support the future IR center. In the late 1950s, the Colegio was small and dedicated exclusively to history and philology, but the Humanities officers wanted to "contribute to more effective long-term development of the Colegio," making it more like a US liberal arts college by expanding into the social sciences. ${ }^{23}$ A second reason was to create synergies between the IR center and the Humanities' interest in area studies. During the war, Fahs had headed the Far Eastern Division in the Research and Analysis branch of the Office for Strategic Services (OSS). Like many other OSS veterans, during the Cold War, Fahs acted as an advocate of area studies (Engerman 2015). ${ }^{24}$ In 1960, Fahs and his deputy, John P. Harrison, were planning to fund a history program at the Colegio whose graduates "would have an awareness and a general knowledge of non-Western cultures as well as one course on Russian and two on United States history." ${ }^{25}$ These officers from Humanities thought that the DSS support would be instrumental in buttressing both area studies and the Colegio as a whole.

In his memoirs, Cosío gives an account of the CEI's beginnings. Cosío suggests that he sought support from the RF and the Mexican government almost simultaneously, in the summer of 1959, a few months before the inauguration of the center. Cosío also writes that the Mexican president forbade him to rely on foreign support. However, he claims to have ignored this veto because he needed RF support to pay the higher salaries of the visiting professors. Cosío also describes RF support as "disinterested and unconditional" (Cosío Villegas 1977, 189). As the following pages show, Cosío's account distorts crucial elements. One is that the patronage granted by the RF and other foreign donors was not a mere supplement to the government's support but a condition set by the Mexican government for the CEI to obtain public funding. Another is the volume and range of RF support, from travel grants to building costs and indirect subsidies via the non-Western history program. In short, Cosío's is an extremely misleading account of RF's role in the birth of CEI.

In its early stages, the negotiations proceeded in fits and starts, and numerous people and issues were involved. For the purposes of this section, they can broadly be summarized as follows: the negotiations began in early 1956, but it took a year for Cosío, the "moving spirit" of the future IR center, to overcome Reyes's resistance to Cosío establishing an escuelita, a "training program" in the social sciences (Lida, Matesanz, and Zoraida 2000, 299). ${ }^{26}$ Reyes's reluctance delayed the Colegio's decision to move into the social sciences until mid-1957, when a visit by Harrison seems to have reignited Cosío's enthusiasm. At this point, Cosío presented a first memorandum on the future IR center, but as shown below this plan flew in the face of

\footnotetext{
${ }^{21}$ Warren Weaver, "N. S. [Natural Sciences], Notes of Officers' Techniques" (1946), pp. 7, 13; RG 3.2, Series 900, Box 23, Folder 127 (hereafter, F127).

${ }^{22}$ For Reyes's standing: Harrison to Reyes, January 9, 1957; RG 1.2, 323R, Box 56, Folder 436, hereafter F436; Yudelman and DeVinney, diary entry, October 25, 1957; RG 2, 1957.323, Box 50, Folder 361, hereafter F361.

${ }^{23}$ Fahs to Cosío, July 26, 1956; RG 2, 1956.323, Box 54, Folder 355.

${ }^{24}$ See "Area Studies: Outline of Humanities Concerns" (1944) and "A Reexamination of Rockefeller Foundation Program in Area Studies" (1954), RG 3.2, Series 900, Box 31, Folder 165.

${ }^{25}$ Grant Action, April 5, 1961; RG 1.2, 323R, Box 54, Folder 428, hereafter F428.

${ }^{26}$ Thompson to Buchanan and Yudelman, October 18, 1957; on Reyes's resistance, Yudelman, trip diary, May 15 , $195 ; \mathrm{F} 485$.
} 
RF policy. Afterward, Cosío and the RF entertained more and increasingly conflictive contacts. ${ }^{27}$ In 1959, Cosío was repeatedly at loggerheads with Rusk, RF's president. This wrangling culminated in a showdown in the second half of 1959 and in a modest, disappointing RF grant to the Colegio, but negotiations continued. Once the CEI had opened its doors in January 1960, Thompson recommended the RF trustees award a more substantial grant. In 1962, a third grant was awarded. The $\mathrm{RF}$ then passed the baton to the FF, which until the 1970s generously funded the Colegio.

\section{The Centro de Estudios Internacionales: IR under Conditionality}

During the negotiations over the future IR center, one RF officer described Cosío "as bright and alert as ever" but looking "old and tired." 28 No wonder, given that Cosío was going through a number of increasingly tense exchanges with the RF while his rivals from the UNAM were also vying for the IR center. Piecemeal and on different occasions, the RF president and officers used those exchanges to transmit Cosío the conditions the Colegio had to fulfil before obtaining an RF grant. This instance of ex-post conditionality can be summarized as follows:

(A) Before granting any award, the RF expected the Mexican government to designate the university or research center that would become the seat of a future IR center. ${ }^{29}$

(B) The RF would only support the Colegio as the new IR center if it managed to attract additional local or foreign sponsors. ${ }^{30}$

(C) Only after the new IR center was operational would the RF consider pledging any form of support. ${ }^{31}$

Condition A, in particular, was a tall order: Rusk was adamant that prior to any award, the Mexican government had to decide where the future IR center would be hosted. The RF wanted the Mexican Foreign Ministry to use the IR center to train future diplomats. ${ }^{32}$ This goal would be jeopardized should the RF choose the IR center's host. Conversely, Cosío thought that back in Mexico, RF support would tilt the balance in favor of the Colegio because his government seemed to be making an endorsement dependent on Cosío attracting foreign, that is, RF, support. To a considerable degree, Cosío was in a catch-22, which made it almost impossible to fulfil conditions A and B.

After Rusk reiterated condition A in a meeting in March 1959, Cosío employed some chutzpah but to no avail. Eager to fulfil condition A and get rid of rivals, Cosío claimed that he had "strong indications of support" from the Mexican government. ${ }^{33}$ However, during a meeting with the Mexican minister of foreign affairs, Harrison found out that no decision in favor of the Colegio had been made. ${ }^{34}$ In the meantime, Cosío had spent the spring trying to get the RF to commit a grant to the Colegio's future IR center. However, such a commitment was, as the Humanities

\footnotetext{
27 "Excerpt from Memorandum from Daniel Cosio Villegas (letter of June 11, 1957). Re: El Colegio de Mexico, Institute of Higher Studies"; Buchanan to Cosío, interview, April 10, 1958; F485; Cosío's letter to Harrison is in RF1.2, 323R, Box 55, Folder 431.

${ }^{28}$ Yudelman, February 24, 1959; RG 12.

${ }^{29}$ Rusk and Thompson to Cosío, interview, March 25, 1959, F485; Harrison to Cosío, interview, June 10, 1959 ; RG 1.2, Box 56, Folder 437, hereafter F437; Rusk to Cosío, interview, August 5, 1959, F485.

${ }^{30}$ Rusk to Cosío, interview, August 5, 1959; Thompson to Cosío, November 2, 1959; F485.

${ }^{31}$ Rusk to Cosío, June 24, 1959, F485.

${ }^{32}$ Rusk and Thompson to Cosío, interview, March 25, 1959, F485.

${ }^{33}$ Rusk and Thompson to Cosío, interview, March 25, 1959; quote is from Harrison to Fahs, June 15, 1959 ; F485.

${ }^{34}$ Harrison, trip diary, June 16, 1959, p. 2, F485.
} 
officers commented, "more than he can hope for at this time." 35 Until the government made a decision, RF patronage was up for grabs.

In early summer, Cosío learned that the RF entertained the idea of granting an award to the UNAM or to a joint UNAM-Colegio IR center, should the Mexican government choose either of these options. Two UNAM-affiliated Mexican international lawyers had persistently proposed their own separate plans to bring the future IR center to their own institutions. ${ }^{36}$ Cosío upped the ante. In a letter to Rusk, he brushed the suggestion of a joint center aside and threatened the RF: he would "give up the whole idea [of the IR center] in view of the Foundation['s] unwillingness to com[e] in." He also ridiculed Thompson's efforts to canvass Mexican opinion on the Colegio's IR plan, calling them "a plebiscite." ${ }^{37}$ After the RF officers read Cosío's letter, the whole CEI project teered on the edge of the abyss. Thompson proposed discarding Mexico and the Colegio outright and rolling out a new search for the Latin American IR center's seat. Most providentially for the Colegio, Fahs from the RF Division of Humanities weighed in. In a deft move, he took steam out of the crisis by pleading for "a fuller talk [with Cosío] in New York, since the question of Colegio or Natl. Univ [UNAM] is not a closed issue but one for further thought and explanation." "38 During the subsequent talk with Cosío, he insisted that the RF should award the grant for the IR center to the Colegio. However, Rusk did not flinch: he "made it clear that [...] it was a question of clarity on the Mexican end with regard to consensus as to appropriate sponsorship." ${ }^{39}$ It was the third time that Rusk made condition A explicit: the Mexican government should make a decision in favor of the Colegio before the RF awarded an IR grant.

Fortunately for Cosío, at the end of the summer, the Mexican government approved his plan. By then, Cosío had spent most of the year going down the blind alley of precipitating a favorable RF decision without fulfilling condition A. The foreign affairs minister, who knew Cosío personally and confirmed his appointment to the ECOSOC, had first forwarded the plan to the minister of education, Jaime Torres Bodet, who had known Cosío since high school (Cosío Villegas 1977, 40). Finally, the Mexican president endorsed the plan submitted by the Colegio. ${ }^{40}$

Undoubtedly, Cosío's relationship with Mexico's corridors of power helped the Colegio defeat the UNAM, but the Cold War also helped. As the foreign minister, Manuel Tello, intimated to Harrison, it "might prove difficult" for other Latin American governments to consider the UNAM, which might be "too big", an appropriate "center for their diplomats." ${ }^{41}$ In reality, indications abounded that communists, specifically from Cuba, had growing influence among students (Pensado 2013; Keller 2017). In view of Tello's worry, it is no wonder that the Mexican government chose the Colegio, a tiny organization led by a reliable liberal like Cosío.

With the Mexican government's "green light to go ahead," in October, Cosío visited Thompson in New York. ${ }^{42}$ Dizzy with success, Cosío made clear that he now expected the RF to make a substantial contribution to the new IR center's library. However, Cosío had overreached. Rusk instructed his officers to temporize:

This file shows the wisdom of occasional reluctance on our part. Cosío is beginning to get his feet on the ground. He seems to have backing as the "chosen instrument"

\footnotetext{
${ }^{35}$ Harrison to Fahs, June 15, 1959, F485.

${ }^{36}$ Francisco Cuevas Cancino to Thompson (Harrison, Fahs, Rusk), August 27, 1959, F485; Sepúlveda to Harrison, trip diary, June 17, 1959, F485.

${ }^{37}$ Rusk to Cosío, June 24, 1959, and Cosío to Rusk, July 10, 1959; F485.

${ }^{38}$ Fahs to Rusk, DeVinney, and Thompson, July 17, 1959, F485.

${ }^{39}$ Rusk to Cosío, interview, August 5, 1959, F485; Tello to the defense minister, October 2, 196, in Archivo Histórico Genaro Estrada (AHGE), "Centro de Estudios Internacionales," SPR-334-15.

${ }^{40}$ Cosío to Thompson, interview, October 29, 1959, F485;

${ }^{41}$ Harrison, trip diary, June 16, 1959, p. 2, F485.

${ }^{42}$ Cosío to Thompson, interview, October 29, 1959, F485.
} 
in Mexico and begins to realize that he is involved in serious business. I would send him $[\ldots]$ a $\$ 10,000$ grant in aid and then keep our eyes on it a bit further. What kind of help does he expect to get apart from the RF? ${ }^{43}$

In this internal note, Rusk insisted on condition B, but the note also had a silver lining: he acknowledged that the government had designated the Colegio as the seat of the future IR center, therefore fulfilling condition A. Condition B, however, led to a new showdown.

By late 1959, condition B (and C) remained to be fulfilled for Cosío to finally open the spigot of RF funding. Cosío knew condition B well. Reacting to a second memorandum Cosío had submitted to RF in early 1959, Rusk had offered Cosío an appointment. During this, Rusk signaled RF interest in a future IR center and its "inter-American" dimension but had simultaneously raised the "question of support." 44 In August, Rusk made it even more explicit to Cosío that the RF wanted "full clarification of problems of sponsorship." ${ }^{45}$ This is precisely what Thompson wrote to Cosío in a deflating letter in which the officer reacted along the lines Rusk set in the quoted internal note. In his first letter after Cosío's triumphal visit in October 1959, Thompson asked him to deliver information on "the assured and anticipated means of support of carrying on your program." Because the RF offered the Colegio only $\$ 10,000$ for the library instead of the $\$ 125,000$ he had hoped for, Cosío sent a furious "riposte," as Thompson called it, in which among other things Cosío labeled him "a hard hearted man." and invited him to formally request $\$ 10,000$ for the library. Internally, Thompson noted that for the RF to grant "any more would be unwise, any less perhaps a missed opportunity." Cosío sent the request for $\$ 10,000 .{ }^{47}$

Decades later, a CEI faculty member surmised that at this point, Thompson had realized that the future IR center would be inaugurated with or without RF support (Meyer 2012, 96). While there might be some truth to this, what the episode also reveals is the extent to which the establishment of the IR center depended on RF financial support. In his riposte, Cosío claimed that the Mexican government had committed " $\$ 8,000$ for 1960 for preparatory work, and up to $\$ 200,000$ over a fiveyear period beginning in 1961." ${ }^{48}$ However, he also confessed to Thompson that the Mexican government had provided funding for an IR center only because Cosío "gave repeated assurances that other [...] institutions [were] ready to help as soon as they were convinced the project was on its way to becoming a reality." In other words, the Mexican government had granted $\$ 8,000$ to enable Cosío to claim to the RF that he was fulfilling the conditions and thereby obtain substantial funding from DSS. By awarding only $\$ 10,000$, the RF had unknowingly put Cosío in another catch-22 situation.

Admittedly, Cosío may have lied to Thompson; however, on this occasion, Cosío's despairing words deserve credibility. The reason is that the RF could have easily used them against the Colegio, as they revealed the extent to which Cosío and his government were banking on the RF assuming most of the costs. Actually, the RF officers had long suspected exactly this. ${ }^{49}$ Despite Cosío's triumphal tone, even the $\$ 200,000$ for a five-year period contributed by the government covered only half

\footnotetext{
${ }^{43}$ Rusk to DeVinney and Thompson, November 16, 1959, F485.

44 "Memorandum," p. 3 (undated), mentioned in Rusk and Thompson to Cosío, interview, March 25, 1959, F485; Harrison had "handed" it to Thompson "on behalf of Cosío."

${ }^{45}$ Rusk to Cosío, interview, August 5, 1959, F485.

${ }^{46}$ Thompson to Cosío, November 17; Cosío to Thompson, November 23, 1959; Thompson, interoffice memorandum, November 30, 1959; all in F485.

${ }^{47}$ Thompson, interoffice memorandum, November 30, 1959; Thompson to Cosío, December 11, 1959; Cosío's response, December 18, 1959; all in F485. Adjusted for inflation, the grant-in-aid for the library amounts to $\$ 87,000$.

${ }^{48}$ Cosío to Thompson, November 23, 1959, F485. Adjusted for inflation, the amounts in question are almost $\$ 70,000$ and $\$ 1,750,000$.

${ }^{49}$ Yudelman, trip diary, May 15, 1956, F485; Harrison, trip diary, December 8, 1956, F485.
} 
of the budget that Cosío provided in his memorandum. There Cosío had implied that "Obviously, RF may contribute a share and it might be possible to attract the interest of the UNESCO.” Interested Latin American governments, Cosío added, could also contribute. ${ }^{50}$ To fund Latin American diplomats and students, Cosío later contacted the fellowship program at the Organization of American States (OAS) ${ }^{51}$ In April 1960, he was still struggling to obtain UNESCO travel support for visiting faculty who could teach area studies. ${ }^{52}$ Condition B was not fulfilled, and Rusk and Thompson kept their eyes on the Colegio a while longer.

In an attempt to fulfil condition C, the Colegio had inaugurated the CEI in January 1960 (Lida, Matesanz, and Zoraida 2000, 326). Still lacking funding, during the first year of the CEI's existence, Cosío identified potential faculty and students, sought a director for the CEI, bought books, and published the first issue of Foro Internacional, but the CEI lacked faculty and students. ${ }^{53}$ By proceeding in this fashion, Cosío responded to Rusk's objection that "the proposed program in international relations at the Colegio" was "still in the planning stage" and not "sufficiently far along" as to interest RF trustees. ${ }^{54}$ Bluntly put, to fulfil condition C, Cosío had inaugurated a Potemkin IR center.

Nonetheless, in July 1960, Thompson reported positively on the CEI to his superiors. In Thompson's opinion, built upon the information dutifully provided by Cosío, condition C had been satisfied: the CEI had progressed from a mere "plan" to becoming one of those "undertakings [...] which are in the being," as Rusk had once put it. ${ }^{55}$ In late summer, the RF awarded a second $\$ 75,000$ grant to the CEI for the library and for visiting professors. ${ }^{56}$ Two years later, a further grant of $\$ 114,125$ for a new building followed. ${ }^{57}$ By then, the RF officers were eager to grant $\$ 491,250$ or more than $\$ 4$ million current dollars to finance economics and demography. ${ }^{58}$ The increasing Cold War tensions, which moved the RF to boost support to Latin American universities (Levy 2005), seem to have helped the Colegio. To sum up, RF officers goaded Cosío into fulfilling condition A, barely fulfilling B, and creating the appearance of C. As the next section shows, RF's ex-post conditionality laid not only the road to the CEI but also molded its early years.

\section{From the Multidisciplinary Study of International Relations to Area Studies and Realism}

In January 1960, the CEI, the first Latin American IR center, was inaugurated. In retrospect, it seems an anomaly to institutionalize IR in a stand-alone department in Mexico, where political science barely existed. As a CEI faculty member once asked, "Why was this center established rather than a political studies one?" (Segovia 2012, 85). According to Colegio lore, in the 1960s the Mexican government preferred to fund (and allow) the study of foreign rather than domestic policy (Meyer 2012, 94). The CEI faculty's questioning demonstrates the pertinence of asking whether the CEI was what the Colegio needed at the time: was the CEI the center that Cosío originally wanted? Or was the CEI molded according to RF policies and Thompson's

\footnotetext{
${ }^{50}$ June 10, 1959; memorandum, Centro de Estudios Internacionales, pp. 9-10, in AHGE, "Centro de Estudios Internacionales," III/380(72) 24; emphasis added; revised, Spanish version of the memorandum submitted in March 1959 to RF, F485.

${ }^{51}$ Cosío to Thompson, November 23, 1959, F485.

${ }^{52}$ Cosío to Thompson, April 19, 1960; RG 1.2, 323S, Box 62, Folder 486, hereafter F486.

${ }^{53}$ Cosío to Thompson, April 19, 1960; June 10, 1960; August 10, 1960; all in F486; Cosío to Thompson, June 22, 1960; RG 2, 1960.323, Reel 38, Frame 846, hereafter F846.

${ }^{54}$ Rusk to Cosío, June 24, 1959, F485.

${ }^{55}$ Thompson, diary entry, July 30, 1960, F486; Rusk to Cosío, June 24, 1959, F485; the word order has been altered.

${ }^{56}$ Adjusted for inflation $\$ 656,000$; award from September 23, 1960, F485.

${ }^{57}$ Adjusted for inflation $\$ 951,000$; award from October 26, 1962; RG 1.2, 323, Box 23, Folder 159 (hereafter, F159).

${ }^{58}$ Hardin to Cosío, interview, April 4, 1963; RG 1.2, 323, Box 23, Folder 160 (hereafter, F160).
} 
realist preferences, such as separating political science from IR? This section probes three essential traits: IR as the CEI's disciplinary backbone, realist theory, and the emphasis on area studies.

Cosío's original idea was to augment and pool scarce resources in sociology, economics, and political science to study international problems from various perspectives in a multidisciplinary IR center. To be sure, Cosío's early contacts with the RF on this matter revolved around a training program for the Mexican Foreign Service. ${ }^{59}$ It is also true that the expression "international relations" appears early in the record and remains until negotiations end. ${ }^{60}$ However, Cosío almost never means IR as a distinct discipline but as a study object. He consciously differentiated between international relations as andemic discipline, which he labels "international relations proper." ${ }^{\dagger}$

During the negotiations, Cosío repeatedly insisted on multidisplicinarity and highlighted how important certain social sciences would be for Mexico. From the beginning and throughout the negotiations, Cosío evoked the Colegio's Centro de Estudios Sociales, a short-lived center with very limited activity in IR but that combined economics, sociology, and political science. ${ }^{62}$ In spring 1957 , he hoped that the Colegio could provide "courses on modern civilization: economics, history, philosophy, political science, sociology, and literature." 63 Sometimes, Cosío insisted on specific disciplines, as when he lectured two DSS officers about how useful sociologists could be for his work as a Mexican diplomat. ${ }^{64}$ On another occasion, Cosío affirmed that he "would like to prepare two to four people in fields like political science and economics." 65 Two months later, Cosío enthusiastically described to Thompson the first prospective students as including "one candidate [who] suggests a program of studies based on political science, another on economics and a third on military matters, while others have chosen the area concept." ${ }^{66}$ As late as 1960, Cosío described the curriculum as being "orientated" toward "economics, law, history and international relations proper." 67

Further evidence confirms that the CEI was not the multidisciplinary center that Cosío originally wanted. Right after the CEI was established, he continued seeking support, this time from the FF, to fund political science research and teaching at the CEI. The FF declined to grant such support: according to FF consultants, it could be "given the overtones of an effort to undermine such political consensus as now exists in the Mexican political system." 68 If Cosío's words and deeds are added up, it seems reasonable to conclude that he intended to bring the Colegio into the social sciences, which seemed most likely if a multidisciplinary center encompassing political science, sociology, and economics could be established, but changes occurred during the negotiations that transformed it into a stand-alone IR center.

As we know, Thompson's IR agenda at the RF aimed at severing IR from political science at least as much as boosting realist IR. Accordingly, he and other RF officers infused the CEI with this realism through solicited and unsolicited advice. A few months after Cosío had first expressed a firm interest in international studies, Thompson had taken him for lunch with John H. Herz, who described his

\footnotetext{
${ }^{59}$ Fahs, diary entry, January 22, 1956, RG 12.

${ }^{60}$ Cosío to Thompson, August 10, 1960, F486.

${ }^{61}$ Cosío to Thompson, August 10, 1960, F486.

${ }^{62}$ Fahs, diary entry, January 17, 1956; Yudelman's diary trip, February 25, 1959; Cosío to Rusk, July 10, 1959; all in F485.

${ }^{63}$ Harrison, trip diary, May 18, 1957, F485; emphasis added.

${ }^{64}$ Cosío to DeVinney and Yudelman, diary entry, October 25, 1957, F361.

${ }^{65}$ Cosío to Thompson, interview, April 19, 1960, F486.

${ }^{66}$ Cosío to Thompson, June 10, 1960, F486.

${ }^{67}$ Cosío to Thompson, August 10, 1960, F486.

${ }^{68}$ Pendleton Herring to James Morrill, December 26, 1962; Cosío to James Morrill, January 15, 1962; John D. Milley to James F. Tierney, February 1, 1962; Ford Foundation collection, Log File 62-0090.
} 
university's IR programs. ${ }^{69}$ Later, Cosío also showed interest, and Thompson took note of it, visiting the Johns Hopkins' "School for Advanced International Studies and talk[ing] with [...] Paul H. Nitze about their program."70

It is unclear whether Cosío was not already sympathetic toward realist ideas, as suggested by his earlier decisions as an editor (Fox 1944; Spykman 1944). Later, while already negotiating with RF, Cosío included realist remarks in his book on Mexican foreign policy ("As if the form of government could deprive a big power of its lust for, its necessity of power and domination," 1960, xxxi). With his publisher hat on again, Cosío asked Thompson for advice on both the outlines of the IR series he was planning and on specific titles: "I have been thinking of Morgenthau's Politics among Nations or [Georg] Schwarzenberger's Power Politics, I know you have a high opinion about the former." 71 Since Thompson found it "inappropriate" to recommend Morgenthau's book, another officer, Hardin, did. ${ }^{72}$ (A translation of Schwarzenberg's Power Politics also appeared in Mexico at the time [1960].) Cosío also asked Thompson to advise him on prospective board members for the CEI's new journal. ${ }^{73}$ In the first two volumes, Cosío published articles by Morgenthau and Thompson. The latter's work was reviewed and so was Niebuhr's. Attention was also given to a theorist of deterrence and arms control like Thomas Schelling. ${ }^{74}$

When Cosío also asked for names of visiting professors who could teach on different world areas, Thompson promptly sent a four-page list. It included a limited number of modernization theorists, that is, Gabriel Almond and Roy Macridis, and Cold Warriors such as the Chicago sociologist Edward Shils, but the usual suspects predominated: committee members from the RF's International Relations Program plus many other realists such as Herz, Herbert Butterfield, E. H. Carr, and someone who became a regular visitor to the Colegio-Jean-Baptiste Duroselle. ${ }^{75}$ The list also included scholars associated with the Council of Foreign Relations such as Erich Hula, a realist international lawyer, and Hans Kohn, the historian of nationalism. Thompson also suggested Sebastian de Grazia, an OSS veteran. ${ }^{76}$

Thompson's advice entailed not only people but also readings. He provided Cosío with "a number of university catalogs and a few articles dealing with approaches to international relations" and referred him to the Carnegie Endowment for International Peace's "series of books on the universities and world affairs."77 Upon Thompson's insistence and with funding from the RF, which had commissioned the Council for Foreign Relations to select an IR library collection for newly independent states' foreign ministries, the Colegio bought a significant share of the recommendations. ${ }^{78}$ Although there is no space here to examine the collection, it is worth mentioning that while a minimum of pluralism was allowed in the list, i.e. Almond's The Appeals of Communism, its thirty-book section on international politics displayed works almost exclusively by realist authors associated with the RF. ${ }^{79}$ To sum up, Thompson provided Cosío with a network of contacts, publications, and advice conductive toward realist IR.

\footnotetext{
${ }^{69}$ Thompson, diary entry, October 10, 1957, F485.

${ }^{70}$ Thompson, diary entry, October 20, 1959, F485.

${ }^{71}$ Cosío to Thompson, March 15, 1960; RG 2, 1960.323; Cosío to Thompson, September 29, 1960 , in F846.

${ }^{72}$ Thompson to Freund, ca. November 14, 1960; Thompson to Hardin, January 13, 1961; F846.

${ }^{73}$ Cosío to Thompson, November 24, 1959, F485.

${ }^{74}$ https://www.jstor.org/journal/forointe.

${ }^{75}$ Thompson to Cosío, December 7, 1960, F486.

${ }^{76}$ Thompson to Cuevas, May 8, 1961, F486.

${ }^{77}$ Thompson to Cosío, October 2, 1959, F485.

${ }^{78}$ Cosío to Thompson, November 26, 1959, F485; Thompson, to a council librarian, February 13, 1958 ; RG 2, 1958.100, Reel 7, Frame 919; RG 3.1, Series 910, Box 7, Folders 65 and 66.

${ }^{79}$ Almost the single exception: Robert Dahl's Congress and Foreign Policy; RG 3.1, Series 910, Box 7, Folders 6-65.
} 
While Cosío may have cherished realist ideas before negotiating with Thompson, no doubt exists that the latter influenced the first two CEI directors. The inaugural one was Francisco Cuevas, a Mexican diplomat and a former Guggenheim Fellow. He was one of the international lawyers that tried in vain to bring the IR center to the UNAM. Nonetheless, Cuevas later accepted the CEI directorship, upon which he expressed his gratitude to Thompson for having been "instrumental in my coming here." Cuevas was so grateful that he volunteered secret reports on the Colegio, in which he expressed his admiration for his "Dear Ken" (allegedly, the reports were "justified" on the basis of "our deep friendship"). ${ }^{80}$ In a letter congratulating Thompson for a new appointment, Cuevas wrote, "I look forward to great achievements" in our field. ${ }^{81}$ Cuevas also restated Cosío's invitation to Thompson to come to Mexico to teach "theory of international affairs." ${ }^{82}$ Cuevas and Thompson agreed that "International Relations is [...] a true discipline." 83 Together with some CEI students, Cuevas eventually translated the opus magnum written by Thompson's teacher's, Politics among Nations (Morgenthau 1963) and later contributed to the Festschrift Thompson edited. Overall, Cuevas admired Thompson so much that he adopted his ideas on all IR matters.

Conscious of Cuevas' loyalty to Thompson, Cosío dismissed him and appointed Mario Ojeda, a young UNAM graduate, as the CEI director (Cosío Villegas 1977, 235). Previously, Thompson awarded him a Rockefeller Fellowship at Harvard and personally supervised Ojeda's study plan; the RF officer Freund oversaw its execution. ${ }^{84}$ While at Harvard, Ojeda took two courses with Stanley Hoffmann. Nonetheless, most of his training was with realists: he took two courses with Morgenthau and further ones with other fellow realists such as Robert Bowie, Reinhold Niebuhr, and Henry Kissinger (Ojeda 1999, 16; Covarrubias Velasco 2014).$^{85}$ Back in Mexico, Ojeda planted realist theory into his syllabus: in 1962, his students at CEI and at the UNAM, where he also taught as an adjunct, read Kissinger's Nuclear Weapons and Foreign Policy (1957) and analyzed Morgenthau's Politics among Nations_-"one chapter after the other" (Gil Villegas 1999, 25; Valero 2012, 407).

While holding the CEI directorship, Ojeda publicly proclaimed his realist commitment. In a 1964 programmatic article, he declared that power was IR's central concept and that the main concern of the discipline should be foreign policy (Ojeda 1964, 88); his main book is considered a hallmark of-Mexican-foreign policy analysis (Ojeda 1976). For decades, Ojeda taught his version of realism to many cohorts of students (Gil Villegas 2009; Saavedra 2009). Ojeda's teaching was key for the "Mexican School of Realism," a "realist foreign policy analysis" that was still practiced at the Colegio and beyond in the late 1980s (Gil Villegas 1989, 261, 283; Saavedra 2009, 310, 339; Ferrer 2012, 168-69). These testimonies by Ojeda's former students reveal that two decades after the RF grants, the realist IR theory still was at the core of the CEI degree.

While only loosely unrelated to realist theory, it should be mentioned here that apart from co-appointing the CEI director, the RF officers also co-selected the CEI's early faculty. Since Mexico lacked the IR scholars necessary to staff the CEI, Cosío sent future faculty members to study abroad, initially only on RF fellowships. Since the RF officers interviewed every single candidate, and the RF policy made the

\footnotetext{
${ }^{80}$ Quotes are from Cuevas to Thompson, February 1, 1961, F486.

${ }^{81}$ Cuevas to Thompson, October 7, 1961, F486.

${ }^{82}$ Cosío to Thompson, November 23, 1959, F485; Thompson to Cuevas, October 5, 1961, RG 1.2, 323S, Box 62, Folder 484 (hereafter F484).

${ }^{83}$ Cuevas to Thompson, January 29, 1962, F486.

${ }^{84}$ Ojeda to Freund, April 17, 1961, RG 10.1, 323E, Box 194, Folder 2932 (hereafter F2932).

${ }^{85}$ Ojeda to Freund in letters from November 26, 1960; February 8, 1961; October 16, 1961; February 20, 1962; all in F2932.
} 
fellowships conditional on Cosío hiring the fellows full time upon their return, they had de facto a veto on who was to become CEI faculty. ${ }^{86}$

While negotiating with the RF, Cosío's plans experienced a third change, this one toward area studies. Initially, Cosío never mentioned them. Only after the first memorandum on the future IR center, which highlighted Mexico's lack of teaching on any world area and on the "history and the problems of the world of our days," did Cosío mention area studies. ${ }^{87}$ This first remark appeared four weeks after "Cosío said [to Harrison that] he had always agreed with CBF [Fahs] that it was ridiculous that United States and Asian economic, social, and political history was not taught in Mexico." Both the timing and Cosío's allusion to Fahs suggest that the idea was not his but was planted by Humanities officers. This memorandum is part of a trend: after May 1957, every time Cosío submitted a document to the RF, the turn toward area studies seems to become more pronounced.

Why the CEI curriculum emphasized area studies (twenty courses) rather than IR (ten) cannot be established with certainty, but it brought the CEI closer to the remit of the Humanities. ${ }^{88}$ Most probably, it resulted from a decision made by Cosío at the eleventh hour, after he realized that the DSS and the Mexican government had granted insufficient support for IR but that the Humanities officers were eager to support area studies courses. This happened shortly after the showdown on problems of sponsorship in November 1959. At that time, Thompson had let Cosío "know that it is most unlikely the Foundation, now or later, would be able to provide a substantial fraction of the operating costs of the new Center." 89 By then, Cosío knew that the Mexican government had awarded the CEI only 60 percent of the amount he had budgeted. Soon after, Cosío, Fahs, and Harrison began to plan a history program at the Colegio. Its graduates "would have an awareness and a general knowledge of non-Western cultures as well as one course on Russian and two on US history." 90 Summoning DSS and Humanities support allowed Cosío to allocate more resources to the future IR center, but Humanities support in turn inevitably further skewed the CEI toward history and area studies. ${ }^{91}$ This eventually moved the DSS to raise questions and Cosío to admit being driven by another patron, UNESCO, whose East West Major Project, the embryo of the Colegio's future Center for Asian and African Studies, initially provided a share of the CEI faculty. ${ }^{92}$ If we add all this up, it is easy to understand how Fahs's (and UNESCO's) area studies-rather than the multidisciplinarity favored by Cosío-wormed their way into the CEI fabric. The other two changes encouraged by Thompson's continuous "advice"-the stand-alone IR center and the realist theory-were also firmly in place. The consequences of these donor-driven changes were perceptible for decades and possibly not only at the Colegio.

\section{Conclusion}

If Cosío's initial plans are compared with the Colegio's CEI, his own claim that "the main point is, of course, our needs" is belied. ${ }^{93}$ In reality, the early CEI only encompassed the narrow intersection of his plans and Thompson's realist interpretation of RF policy. This was the main point, not the Colegio's needs. In the late 1950s, Cosío had envisioned an IR center in which scholars would conduct teaching and

\footnotetext{
${ }^{86}$ Thompson to Cosío, August 17, 1960; Cosío to Thompson, August 23, 1960; RG 2, 1960.323; RG 10.1, 323E.

${ }^{87}$ Harrison, interview, May 18, 1957; Cosío, memorandum, June 11, 1957; F485.

88 "Memorandum. Kenneth W. Thompson in regard to a Center of International Studies," undated, F486 (Ochoa 2011, 68-70).

${ }^{89}$ Thompson to Cosío, November 17, F485.

${ }^{90}$ José Miranda to Harrison, November 28, 1959, F437; Cosío to Harrison, December 10, 1959 , F428.

${ }^{91}$ Correspondence in late 1960 and early 1961; F486 and F428.

${ }^{92}$ Cosío to Freund, August 31, 1962; Hardin's phone conversation with Cosío on October 5, $1962 ;$ F159.

${ }^{93}$ Cosío to Thompson, November 23, 1959, F485.
} 
research in sociology, economics, and political science. However, the CEI became a stand-alone IR department, its scope narrowed to IR plus area studies. In particular, non-Western area studies were driven by donors: the RF and UNESCO. To be sure, Cosío had also realized some of his goals: he had outmaneuvered his UNAM rivals and completed the tightrope act leading to the first Latin American IR center. And still, RF impact shows that sometimes donors are the engine of a disciplinary history that donors' money fuel.

Turning from donor impact on the CEI and its disciplinary boundaries to impact on theory, it is beyond doubt that at CEI, Thompson and his Mexican allies institutionalized their version of realism. Their version circumvented the thinking of British and US elites and emphasized the Germanic and Weberian notes played by Morgenthau's classical realism. Consequently, in the following decades, the Mexican heirs eschewed both behaviorism and second-generation realists. The RF's former Mexican fellows and their students instead favored topics dear to classical realism (Guilhot 2011b, 2017, chap. 1; Koskenniemi 2004, 460-68): power, diplomacy, and foreign policy analysis. Ironically, as the CEI opened its doors, realism was already being displaced in the United States, mainly by Waltz's neorealism (Guilhot 2017, chap. 6). As this happened, realism enjoyed a Mexican afterlife. Finally, the RF had an impact on the early CEI's personnel, directly on its first directors and indirectly on its early faculty. Using Weberian terms to overstate my case, the early CEI was a heteronomous and heterocephalous organization, whose internal normswhat should be considered part of IR-and personnel were set by the donor.

If science patronage rarely achieves its original goals, how should these findings be explained? Unlike in the U.S. where patronage was available from the US government, military, and foundations (McCaughey 1984; Solovey 2013; Oren 2003, chap. 4; Engerman 2010), in the late 1950s in Mexico, the RF was almost the only IR patron in a field deprived of resources. Even the Mexican government's patronage was conditioned on the RF's. This monopsony seems to explain why during the CEI's early years, the "clumps of indeterminacy" notwithstanding (Turner 1999, 218), causal links connecting patronage to disciplinary boundaries, area studies, and IR realism appear discernable. Here, I examine two causes that operated at the individual level— the RF officers and Cosío-and two at organizational levelconditionality (RF) and legitimacy (Colegio). None of these causes is sufficient, although all were necessary for the RF to wield influence over the early CEI and beyond.

If we first consider the officers, Thompson seems immediately exceptional. After his rapid ascendancy at the RF, he held an unusually firm grip on the DSS. Similarly exceptional seems the veiled protection that Fahs granted to what was in principle a DSS project. With some UNESCO help, Fahs managed to provide the CEI with a non-Western area studies angle. However, exceptional as these two RF directors were, Cosío is even more extraordinary. Both the Mexican political elites and the foundation officers respected him as a liberal scholar who had already had "remarkable success in a series of pioneering ventures" in culture and academia. ${ }^{94}$ Furthermore, this academic entrepreneur was close to Mexico's corridors of power and was free of any suspicion of communism. In an unusual degree, he combined political and two types of scientific capital-both "a capital of strictly scientific authority, and a capital of power over the scientific world" (Bourdieu 2004, 57).

Arguably, the single-most crucial cause that explains RF impact is ex-post conditionality. The RF resisted Cosío's pressure to award support without the Mexican government deciding in favor of the Colegio as the seat of the IR center, the Colegio presenting evidence of having obtained additional support for the CEI, or its previous opening. The period during which Cosío worked strenuously to fulfil these conditions opened a door for RF impact in organizational, disciplinary, and theo-

\footnotetext{
${ }^{94}$ Thompson, diary entry, July 28, 1960, F486.
} 
retical terms. The concept of "structural conditionality" comes to mind (Babb and Carruthers 2008, 18). Without doubt, the RF resorted to ex-post conditionality, which could effectively unfold its effects from within the Colegio because Cosío believed to a significant extent in the legitimacy of the donor's conditions. As Cosío himself summarized, for fifteen years "the Foundation and El Colegio de Mexico have been working together [...] on the usual fifty-fifty basis." 95 To use Max Weber's words $(2019,111)$, the "position of the interests" [Interessenlage] facilitated Cosío perceiving RF conditions as legitimate.

Such a scale of support brought external legitimacy, but it was buttressed by a considerable measure of internal legitimacy. One of the strategies to internally legitimize conditionality is expertise (Best 2012), which the RF used to convince its Mexican counterparts that RF conditions should be fulfilled. Such "expert knowledge" is at the heart of any rational domination and boosts its effectiveness (Weber 2019, 350-52). As shown earlier, Cosío asked Thompson to advise him on many accounts and the reason why Cosío did so is most revealing: he thought that Thompson had "much more knowledge and experience." 96 On another occasion, Cosío wrote Hardin that Thompson was "a man exceptionally well placed to give advice." One is tempted to write that Cosío, and Cuevas even more, perceived Thompson's advice to be not only "rational" but also "exemplary," as if proffered by a charismatic leader (Weber 2019, 115). In brief, material interest and intellectual respect legitimated the RF's conditions, to the extreme that Cosío never dared to confess to RF that he had fired Cuevas, Thompson's protégé. ${ }^{98}$ The in-depth study of a donorrecipient relation conducted in this article confirms that the explanatory potential of legitimacy is diminished if it is reduced to the ideal, normative reasons to obey (Hurd 1999, 381; 2019). This study also put flesh into the bones of the literature on legitimation practices (Tallberg and Zürn 2019, 588), showing how donors can use knowledge to prevail. As Ian Hurd recently admitted, IR literature on legitimacy "owes a lot - though perhaps not quite enough [...] - to Max Weber on authority" (Hurd 2019, 720).

The RF impact on the Colegio should be part of the explanation of how contemporary Mexican IR has developed up to the present. Whatever happens in an emerging field like Mexican IR in the 1960s is likely to have lasting effects (Bourdieu 1992, 465-510; Sending 2015, 28). This appears confirmed by the current separation of IR from political science, which is remarkably common in Mexico: there are no stand-alone political science departments encompassing IR as a subfield. ${ }^{99}$ Undergraduate IR degrees (fifty) are almost as common as political science ones (seventy). ${ }^{100}$ Finally, professional associations also exist separately; the IR one is stronger and recently celebrated its fiftieth anniversary while in 2010 the political science association had to be refounded (Suárez-Iñiguez 2014, 181).

Compared with its impact on Mexican IR, the RF's gravitational pull elsewhere in the region must have been limited but perhaps still perceptible. When in the late 1970s, the Latin American IR began to grow, "Morgenthauian realism" was at the center of adaptations like the Latin American hybrid and peripheral realism (Tickner 2003, 336, 344). To explain realism's ubiquity, Tickner resorts to remote causes such as IR scholars' frustrated political ambitions, US power in the hemisphere, the centrality of the state in Latin America, and the ignorance of alternative IR theories (Tickner 2002, 130; 2003, 343). Here, I propose a more immediate cause: RF support of realism at the CEI, which had an inter-American dimension. In the early 1960s, the CEI attracted a few Latin Americans to the CEI. Later, in the

\footnotetext{
${ }^{95}$ Cosío to Thompson, November 23, 1959, F485; see also Cosío to Harrison, June 11, 1959 , F437.

${ }^{96}$ Cosío to Thompson, August 10, 1960, F486.

${ }^{97}$ Cosío to Hardin, October 5, 1962, F159; word order altered.

${ }^{98}$ Freund, trip diary, June 9, 1962, F486.

${ }^{99}$ The websites of all institutions offering IR or political science degrees were examined.

${ }^{100}$ Three universities offer double degrees; see Anuarios Estadísticos de Educación Superior 2017-2018.
} 
1970s, larger numbers of young exiled South American IR scholars spent crucial, formative years at Mexican institutions where the CEI faculty and graduates taught. After the military dictatorships, some returned home (Tickner 2002, 130; Tenorio Trillo 2009, 106-13). As they fanned out to other parts of the hemisphere, they may have carried realist ideas with them. The books by realist authors available in Spanish should also be included in a full account of realism's Latin American reception.

Within the region, the establishment of the CEI remained an isolated event. Outside Mexico, IR degrees did not exist in Latin America until the mid-1970s. Global IR scholars think that this reflects the "thinness, weakness and newness of academic IR in the periphery" during the 1960s (Acharya and Buzan 2019, 166). However, the sixteen-year gap between the last Rockefeller grant to the CEI and the FF's new IR program on IR is almost the same that separates the CEI and Brasilia's IR degree. If the whole global south is considered, the IR center whose establishment is closer in time to the CEI is New Delhi's ISIS, which received FF and RF funding. Perhaps it is not casual that in India and South Asia, realism "dominates the International Relations discipline" (Behera 2009, 134). In any case, without the post-Bandung foundation support, the CEI and ISIS would not have opened their doors.

If individual donors manage to have specific, even arguably idiosyncratic impacts, then these findings possess implications for the IR literature on donors and on NGOs generally. First, not all donors' agendas are or were homogenized by management tools neither can all of them be subsumed into market forces (Cooley and Ron 2002; Krause 2014). Second, a plurality of donors is not necessary to curb a recipient's autonomy (Stroup and Wong 2017); one donor with a clear-cut policy and apt officers may be enough. Third, an INGO mediating between donors promoting democracy and transitional states may actually not mediate but act according to rules set by the donor and be operated by staff members favored by the donor (Bush 2015). IR scholarship, in conclusion, could benefit from more in-depth studies of donors like philanthropic foundations (Fejerskov 2018; Wong, Levi, and Deutsch 2017).

Finally, some readers may feel confirmed in their belief that global IR "tracks quite closely" to IR as Acharya and Buzan claim (Acharya and Buzan 2019, 2). Others will see here the US foreign policy elite personified by Rusk steering the Latin American reception of realism, resulting in cultural hegemony (Parmar 2012; Huo and Parmar 2020, 20). My persuasion is that the case at hand suggests otherwise. For one, foundation officers specified RF policy in ways that furthered their own professional projects such as realist IR and the study of non-Western areas. Then, these and other causes commingle. Some of the other causes are highly contingentthink of Buchanan's death, Rusk's appointment as the secretary of state, and Fahs's deftness in shielding Cosío from the consequences of his temper tantrums. Such contingent events, just like a Bandung conference and Cuba's turn toward Moscow, were necessary but not sufficient causes through which world politics seeped into the disciplinary history of global IR.

\section{Funding}

Martha van Bakel's assistance is gratefully acknowledged as well as the support from the Einstein Stiftung Berlin, the Cluster of Excellence "Contestations of the Liberal Script" (EXC 2055, Project-ID: 390715649), funded by the Deutsche Forschungsgemeinschaft (DFG, German Research Foundation), and the European Union's Horizon 2020 program (Marie Skłodowska-Curie grant agreement 702562).

\section{References}

Acharya, Amitav. 2014. "Global International Relations (IR) and Regional Worlds." International Studies Quarterly 58 (4): 647-59. 
Acharya, Amitav, and Barry BuZan. 2010. Non-Western International Relations Theory: Perspectives on and beyond Asia. London: Routledge.

- 2019. The Making of Global International Relations: Origins and Evolution of IR at Its Centenary. Cambridge: Cambridge University Press.

Alejandro, Audrey. 2018. Western Dominance in International Relations? The Internationalisation of IR in Brazil and India. London: Routledge.

Ashworth, Lucian M. 2014. A History of International Thought: From the Origins of the Modern State to Academic International Relations. London: Routledge.

BabB, SARAH L. 2001. Managing Mexico: Economists from Nationalism to Neoliberalism. Princeton, NJ: Princeton University Press.

Babb, Sarah L., and Bruce G. Carruthers. 2008. "Conditionality: Forms, Function, and History." Annual Review of Law and Social Science 4: 13-29.

Behera, Navnita Chadha. 2009. "South Asia: A 'Realist' Past and Alternative Futures.” In International Relations Scholarship around the World, Worlding beyond the West, edited by Arlene B. Tickner and Ole Wæver, 134-57. Abingdon: Routledge.

Berman, Edward H. 1983. The Influence of the Carnegie, Ford, and Rockefeller Foundations on American Foreign Policy: The Ideology of Philanthropy. Albany, NY: State University of New York Press.

BEST, JACQUELINE. 2012. "Ambiguity and Uncertainty in International Organizations: A History of Debating IMF Conditionality.” International Studies Quarterly 56 (4): 674-88.

Bourdieu, Pierre. 1992. Les règles de l'art: Genèse et structure du champ littéraire. Paris: Éd. du Seuil. - 2004. Science of Science and Reflexivity. Chicago, IL: University of Chicago Press.

Bush, Sarah S. 2015. The Taming of Democracy Assistance: Why Democracy Promotion Does Not Confront Dictators. Cambridge: Cambridge University Press.

Clark, Ann M. 2001. Diplomacy of Conscience: Amnesty International and Changing Human Rights Norms. Princeton, NJ: Princeton University Press.

Cohen, Warren I. 1980. Dean Rusk. Totowa, NJ: Cooper Square.

Cooley, Alexander, and James Ron. 2002. "The NGO Scramble: Organizational Insecurity and the Political Economy of Transnational Action.” International Security 27 (1): 5-39.

Cosío Villegas, Daniel. 1960. El Porfiriato: La vida política exterior. Parte 1. México: Hermes. 1977. Memorias. México: Joaquín Mortiz.

Covarrubias Velasco, Ana. 2014. “Obituario: Mario Ojeda Gómez.” Foro Internacional 54 (1): 206-10.

Cox, Robert W. 1983. "Gramsci, Hegemony and International Relations: An Essay in Method." Millennium: Journal of International Studies 12 (2): 162-75.

Donnelly, Jack. 1995. "Realism and the Academic Study of International Relations." In Political Science in History: Research Programs and Political Traditions, edited by James Farr, John S. Dryzek and Stephen T. Leonard, 175-97. Cambridge: Cambridge University Press.

Engerman, David C. 2010. "Social Science in the Cold War." Isis; An International Review Devoted to the History of Science and Its Cultural Influences 101: 393-400.

- 2015. "The Pedagogical Purposes of Interdisciplinary Social Science: A View from Area Studies in the United States." Journal of the History of the Behavioral Sciences 51 (1): 78-92.

Fejerskov, Adam Moe. 2018. The Gates Foundation's Rise to Power: Private Authority in Global Politics. Abingdon: Routledge.

Ferrer, Carlos. 2012. "El primer director del Centro de Estudios Internacionales: Francisco Cuevas Cancino." In El Centro de Estudios Internacionales de El Colegio de México: 50 años de investigación y docencia, edited by Gustavo Vega and Humberto Garza, 165-72. México: El Colegio de México.

Fierke, Karin M., and Vivienne Jabri. 2019. "Global Conversations: Relationality, Embodiment and Power in the Move towards a Global IR.” Global Constitutionalism 8 (3): 506-35.

Fisher, Donald. 1993. Fundamental Development of the Social Sciences: Rockefeller Philanthropy and the United States Social Science Research Council. Ann Arbor, MI: University of Michigan Press.

Forsythe, David P. 2005. The Humanitarians: The International Committee of the Red Cross. Cambridge: Cambridge University Press.

Foulon, Michiel, and Gustav Meibauer. 2020. "Realist Avenues to Global International Relations." European Journal of International Relations 26 (4): 1203-29.

Fox, William Thornton Rickert. 1944. Las Superpotencias Estados Unidos, Inglaterra y La Unión Soviética. Su Responsabilidad Ante La Paz. México: Fondo de Cultura Económica.

Frei, Christoph. 2018. "Politics among Nations: A Book for America." In Hans J. Morgenthau and the American Experience, edited by Cornelia Navari, 55-74. Cham: Palgrave.

Freund, Gerald. 1996. Narcissism and Philanthropy: Ideas and Talent Denied. New York: Viking.

Gaddis, John Lewis. 2006. The Cold War: A New History. New York: Penguin Books.

Gil-Villegas, Francisco. 1989. "El estudio de la política exterior en México: enfoques dominantes, temas principales y una propuesta teórico-metodológica.” Foro Internacional 29 (116): 662-92. 
1999. “Mario Ojeda: profesor emérito.” Boletín Editorial de El Colegio de México 80: 24-9.

2009. "Las fuentes germánicas de Morgenthau y la vigencia del realismo político: homenaje a la obra de Mario Ojeda." In "Alcances y Limites de La Politica Exterior de México" Ante el Nuevo Escenario Internacional: Ensayos En Honor de Mario Ojeda, edited by Gustavo Vega, 259-87. México: El Colegio de México.

Gilman, NiLs. 2003. Mandarins of the Future: Modernization Theory in Cold War America. Baltimore, MD: Johns Hopkins University Press.

Guilhot, Nicolas. 2011a. "Introduction. One Discipline, Many Histories." In The Invention of International Relations Theory: Realism, the Rockefeller Foundation, and the 1954 Conference on Theory, edited by Nicolas Guilhot, 1-32. New York: Columbia University Press.

- ed. 2011b. The Invention of International Relations Theory: Realism, the Rockefeller Foundation, and the 1954 Conference on Theory. New York: Columbia University Press.

. 2011c. "The Realist Gambit. Postwar American Political Science and the Birth of IR Theory." In

The Invention of International Relations Theory: Realism, the Rockefeller Foundation, and the 1954 Conference on Theory, edited by Nicolas Guilhot, 128-61. New York: Columbia University Press.

. 2014. "Imperial Realism: Post-War IR Theory and Decolonisation." The International History Review 36 (4): 698-720.

. 2017. After the Enlightenment Political Realism and International Relations in the Mid-Twentieth Century. New York: Cambridge University Press.

Hauptmann, Emily. 2012. "The Ford Foundation and the Rise of Behavioralism in Political Science." Journal of the History of the Behavioral Sciences 48 (2): 154-73.

- 2020. “The Theorists' Gambit: Kenneth Thompson's Cultivation of Theoretical Knowledge About Politics during the Early Cold War." The International History Review 42 (3): 625-38.

Hobson, John M. 2012. The Eurocentric Conception of World Politics: Western International Theory, 1760-2010. Cambridge: Cambridge University Press.

Hopgood, Stephen. 2013. Keepers of the Flame: Understanding Amnesty International. Ithaca, NY: Cornell University Press.

Huo, Shuhong, and Inderjeet Parmar. 2020. “'A New Type of Great Power Relationship’? Gramsci, Kautsky and the Role of the Ford Foundation's Transformational Elite Knowledge Networks in China.” Review of International Political Economy 27 (2): 234-57.

Hurd, IAN. 1999. "Legitimacy and Authority in International Politics." International Organization 53 (2): 379-408.

- 2019. "Legitimacy and Contestation in Global Governance: Revisiting the Folk Theory of International Institutions." Review of International Studies 14: 717-29.

Hurrell, Andrew. 2016. "Towards the Global Study of International Relations." Revista Brasileira de Polãtica Internacional 59 (2).

Jatobá, Daniel. 2013. "Los desarrollos académicos de las Relaciones Internacionales en Brasil: elementos sociológicos, institucionales y epistemológicos." Relaciones Internacionales 22: 27-46.

Keck, Margaret E., and Kathryn Sikkink. 1998. Activists beyond Borders: Advocacy Networks in International Politics. Ithaca, NY: Cornell University Press.

Keller, Renata. 2017. Mexico's Cold War: Cuba, the United States, and the Legacy of the Mexican Revolution. New York: Cambridge University Press.

Kissinger, Henry. 1957. Nuclear Weapons and Foreign Policy. New York: Harper.

Koskenniemi, Martti. 2004. The Gentle Civilizer of Nations: The Rise and Fall of International Law 1870-1960. Cambridge: Cambridge University Press.

Krause, Monika. 2014. The Good Project: Humanitarian Relief NGOs and the Fragmentation of Reason. Chicago, IL: University of Chicago Press.

Krauze, Enrique. 2001. Daniel Cosí Villegas: una biografía intelectual. México: Tusquets.

Kuklick, Bruce. 2007. Blind Oracles. Intellectuals and War from Kennan to Kissinger. Princeton, NJ: Princeton University Press.

Kuru, Deniz. 2017. "Who F(o)unded IR: American Philanthropies and the Discipline of International Relations in Europe." International Relations 31 (1): 42-67.

Levy, Daniel C. 1996. Building the Third Sector: Latin America's Private Research Centers and Nonprofit Development. Pittsburgh, PA: University of Pittsburgh Press.

- 2005. To Export Progress. The Golden Age of University Assistance in the Americas. Bloomington, IN: Indiana University Press.

Lida, Clara E. 2018. "The Institutional Reception of Spanish Émigré Intellectuals in Mexico: The Pioneering Role of La Casa de España, 1938-1940." In European and Latin American Social Scientists as Refugees, Émigrés and Return-Migrants, edited by Ludger Pries and Pablo Yankelevich, 205-20. New York: Palgrave Macmillan. 
Lida, Clara E., José Antonio Matesanz, and Josefina Zoraida. 2000. La Casa de España y El Colegio de México. Memoria 1938-2000. México: El Colegio de México.

McCaughey, Robert A. 1984. International Studies and Academic Enterprise. A Chapter in the Enclosure of American Learning. New York: Columbia University Press.

McCourt, David M. 2020. American Power and International Theory at the Council on Foreign Relations, 195354. Ann Arbor, MI: University of Michigan Press.

Meyer, Lorenzo. 2012. "Presente en el arranque y desde el inicio." In El Centro de Estudios Internacionales de El Colegio de México: 50 años de investigación y docencia, edited by Gustavo Vega and Humberto Garza, 91-110. México: El Colegio de México.

Morcillo Laiz, Álvaro. 2019a. "Foreign Policy Expert as a Vocation.” In World Politics as a Vocation Max Weber's Politik als Beruf at 100. Berlin (WZB), 18 January. Berlin: Social Science Center Berlin.

— 2019b. "La Gran Dama: Science Patronage, the Rockefeller Foundation and the Mexican Social Sciences in the 1940s." Journal of Latin American Studies 51 (4): 829-54.

Morgenthau, Hans J. 1963. La lucha por el poder y por la paz. Buenos Aires: Editorial Sudamericana.

OchoA, Luis. 2011. La carrera de relaciones internacionales en México: orígenes y situación actual. México: El Colegio de México; Benemérita Universidad Autónoma de Puebla.

OJEDA, MARio. 1964. "Problemas básicos en el estudio de las relaciones internacionales." Foro Internacional 5 (1): 84-98.

—. 1976. Alcances y límites de la política exterior de México. México: Colegio de México.

. 1999. "Retrato con el Colegio de México de fondo." Boletín Editorial de El Colegio de México 80: 14-23.

Oren, IDO. 2003. Our Enemies and US: America's Rivalries and the Making of Political Science. Reprint Edition. Ithaca, NY: Cornell University Press.

Ortoll, Servando, and Pablo Piccato. 2011. "A Brief History of the Historia Moderna de México." In A Companion to Mexican History and Culture, edited by William H. Beezley, 339-60. Chichester, MA: Wiley.

Parmar, Inderjeet. 2012. Foundations of the American Century: The Ford, Carnegie, and Rockefeller Foundations in the Rise of American Power. New York: Columbia University Press.

Pensado, Jaime M. 2013. Rebel Mexico: Student Unrest and Authoritarian Political Culture during the Long Sixties. Stanford, CA: Stanford University Press.

Rajaee, Farhang. 2016. Kenneth W. Thompson, the Prophet of Norms: Thought and Practice. New York: Palgrave Macmillan.

Rietzler, Katharina. 2008. "Philanthropy, Peace Research, and Revisionist Politics: Rockefeller and Carnegie Support for the Study of International Relations in Weimar Germany." Bulletin of the German Historical Institute Washington 5: 61-79.

2. 2009. "American Foundations and the 'Scientific Study' of International Relations in Europe, 1910-1940.” Doctoral dissertation, University College London.

- 2014. "Fortunes of a Profession: American Foundations and International Law, 1910-1939." Global Society 28 (1): 8-23.

Rockefeller Foundation. 1957-1964. Annual Reports. New York: Rockefeller Foundation.

Romero, Alfredo. 1981. "In Search of a Discipline: The Development of the Field of International Relations in Mexico." The Developing Economies 19 (3): 255-70.

Rusk, Dean. 1959. "The President.” Foreign Affairs 38: 353-69.

- 1990. As I Saw It, edited by Richard Rusk and Daniel S. Papp. New York: Norton.

Russell, Greg. 2018. "Morgenthau in America: The Legacy." In Hans J. Morgenthau and the American Experience, edited by Cornelia Navari, 153. Cham: Palgrave.

Rutherford, Malcolm. 2011. The Institutionalist Movement in American Economics, 1918-1947. Science and Social Control. Cambridge: Cambridge University Press.

SAavedra, Horacio. 2009. "El realismo político: paradigma pragmático y piedra angular de las teorías de las Relaciones Internacionales." In "Alcances y límites de la politica exterior de México" ante el nuevo escenario internacional: ensayos en honor de Mario Ojeda, edited by Gustavo Vega, 305-52. México: El Colegio de México.

Schwarzenberger, Georg. 1960. La política del poder: estudio de la sociedad internacional. México: Fondo de Cultura Económica.

Segovia, Rafael. 2012. "Las comidas de los lunes." In El Centro de Estudios Internacionales de El Colegio de México: 50 años de investigación y docencia, edited by Gustavo Vega and Humberto Garza, 81-90. México: El Colegio de México.

Sending, Ole Jacob. 2015. The Politics of Expertise. Competing for Authority in Global Governance. Ann Arbor, MI: University of Michigan Press.

Shahi, Deepshiкha. 2018. Advaita as a Global International Relations Theory. Abingdon: Routledge. 
Sikkink, Kathryn. 1998. "Development Ideas in Latin America: Paradigm Shift and the Economic Commission for Latin America." In International Development and the Social Sciences: Essays on the History and Politics of Knowledge, edited by Frederick Cooper and Randall M. Packard, 228-56. Berkeley, CA: University of California Press.

Sluga, Glenda, and Patricia Clavin. 2016. "Rethinking the History of Internationalism.” In Internationalisms: A Twentieth-Century History, edited by Glenda Sluga and Patricia Clavin, 13-16. Cambridge: Cambridge University Press.

Solovey, Mark. 2013. Shaky Foundations. The Politics-Patronage-Social Science Nexus in Cold War America. New Brunswick, NJ: Rutgers University Press.

- 2020. Social Science for What?: Battles over Public Funding for the "Other Sciences" at the National Science Foundation. Cambridge, MA: MIT Press.

Spykman, Nicholas John. 1944. Estados Unidos frente al mundo. México: Fondo de Cultura Económica.

Stroup, Sarah S., And Wendy H. Wong. 2017. The Authority Trap. Strategic Choices of International NGOs. Ithaca, NY: Cornell University Press.

SuÁrEZ-IÑIgUEZ, ENRIQUE. 2014. "El largo camino hacia la autonomía y la institucionalización de la ciencia política en México y en el mundo." Estudios Políticos 31: 165-83.

Swedlund, Haley J. 2017. The Development Dance: How Donors and Recipients Negotiate the Delivery of Foreign Aid. Ithaca, NY: Cornell University Press.

Tallberg, Jonas, and Michael Zürn. 2019. "The Legitimacy and Legitimation of International Organizations: Introduction and Framework.” The Review of International Organizations 14 (4): 581-606.

Tenorio Trillo, Mauricio. 2009. "Orígenes del Centro de Investigación y Docencia Económicas. A.C." In 35 Años Del CIDE, edited by Mauricio Tenorio, 5-34. México: CIDE.

Thompson, Kenneth W. 1965. "The New Diplomacy and the Quest for Peace." International Organization 19 (3): 394-409.

Thornton, Christy. 2021. Revolution in Development. Mexico and the Governance of the Global Economy. Oakland, CA: University of California Press.

TickNer, ArLene B. 2002. Los estudios internacionales en América Latina: Subordinación intelectual o pensamiento emancipatorio? Bogotá: Universidad de los Andes y Alfaomega.

_ 2003. "Hearing Latin American Voices in International Relations Studies." International Studies Perspectives 4 (4): 325-50.

- 2013. "Core, Periphery and (Neo)Imperialist International Relations." European Journal of International Relations 19 (3): 627-46.

Tickner, Arlene B., And David L. Blaney, eds. 2012. Thinking International Relations Differently. New York: Routledge.

Tickner, Arlene B., And Ole Wæver, eds. 2009. International Relations Scholarship around the World. Abingdon. Oxon: Routledge.

Turner, Stephen P. 1999. "Does Funding Produce Its Effects? The Rockefeller Case." In The Development of the Social Sciences in the United States and Canada: The Role of Philanthropy, edited by a R. Richardson and Donald Fisher, 213-26. Stamford, CT: Ablex.

2008. "Hans J. Morgenthau and the Legacy of Max Weber." In Political Thought and International Relations: Variations on a Realist Theme, edited by Duncan Bell, 63-82. Oxford: Oxford University Press.

Valero, Ricardo. 2012. "Memorias Del Centro de Estudios Internacionales." In El Centro de Estudios Internacionales de El Colegio de México: 50 años de investigación y docencia, edited by Gustavo Vega and Humberto Garza, 393-413. México: El Colegio de México.

VÉliz, Claudio. 1967. "El Instituto de Estudios Internacionales de la Universidad de Chile." Estudios Internacionales 1 (1): 3-7.

Weber, Max. 2019. Economy and Society: A New Translation. Cambridge, MA: Harvard University Press.

Wong, Wendy H., Ron Levi, and Julia Deutsch. 2017. "Domesticating the Field: The Ford Foundation and the Development of International Human Rights." In Professional Networks in Transnational Governance, edited by Leonard Seabrooke and Lasse Folke Henriksen, 82-100. Cambridge: Cambridge University Press.

Zeiler, Thomas W. 1999. Dean Rusk: Defending the American Mission Abroad. Wilmington, NC: Rowman \& Littlefield. 